\title{
A preliminary report of a surveillance scheme of occupational asthma in the West Midlands
}

\author{
Paul F G Gannon, P Sherwood Burge
}

\begin{abstract}
The results from the first year of a notification scheme for occupational asthma in the West Midlands Region are presented. The scheme includes recognised new and old cases of occupational asthma. Thirty new cases were recognised per million general working population in the first year. Cases recognised in different occupational groups ranged from 154 per million painters and assembly workers to three per million clerical staff. Analysis of the agents to which workers with recognised occupational asthma were exposed identified commonly recognised agents such as isocyanates, colophony, and flour and generally less well recognised ones such as oil mists. The distribution of new and old reported cases, including those receiving compensation from the Department of Social Security, were calculated by health authority using estimated working population as the denominator. The number of reported cases varied from 303 per million in a semi-urban health authority that has a respiratory physician with a special interest in occupational asthma to less than $\mathbf{3 0}$ cases per million in eight health authorities. The most likely cause for these differences is lack of ascertainment.
\end{abstract}

Occupational asthma is asthma that is caused by agents inhaled in the workplace. At present little is known about its incidence in the general working population or in specific occupations. To our knowledge only two defined population based studies have been performed. Blanc ${ }^{1}$ found a prevalence of occupational asthma of 12000 per million of the disabled population in the United States and

Occupational Lung Disease Unit, East Birmingham Hospital, Bordesley Green East, Birmingham B9 5ST

P F G Gannon, P S Burge

(on behalf of the Midland Thoracic Society Research Group; J G Ayres, R B Cole, S Connellan, D Honeybourne, C F A Pantin)
Keskinen $e t \mathrm{al}^{2}$ found an annual incidence of 35 per million of the general working population in Finland in 1978. The surveillance of work related and occupational respiratory diseases (SWORD) project looking at a number of different work related respiratory diseases is ongoing and interim results suggest an overall incidence of 22 per million in the United Kingdom. ${ }^{3}$ Other studies have estimated the prevalence of occupational asthma to be between $2 \%$ and $15 \%$ of adult asthmatic subjects. ${ }^{45}$ Of these studies only the paper by Keskinen $e t a^{2}$ and the SWORD project ${ }^{3}$ have attempted to produce an incidence for specific occupational groups.

Numerous cross sectional studies have been performed to determine the prevalence of occupational asthma in given workplaces-for example, a prevalence of $22 \%$ was seen in an electronics factory ${ }^{6}$ and one of $13 \%$ in a bakery. ${ }^{7}$ These figures cannot be extrapolated to the exposed population in general and may not be representative of all workplaces where a specific occupation is pursued. Also, whenever cross sectional studies have followed identification of index cases other cases have been identified, suggesting that occupational asthma is generally underdiagnosed.

This article describes the results at one year of a prospective survey of a working population within a defined geographical area, namely that served by the West Midlands Regional Health Authority. This area has a population of $5 \cdot 1$ million and a working population of $2 \cdot 2$ million. It encompasses the heavily industrialised areas in and around Birmingham, Coventry, and Stoke on Trent, together with agricultural areas around Warwick, Shrewsbury, Hereford, and Worcester. The intention of the survey was to produce an annual incidence for recognised occupational asthma within the region in the general working population and in specific occupational groups.

\section{Methods}

Starting in January 1989, doctors within the West Midlands Region who were likely to recognise cases of occupational asthma were asked to report these to a central registry each month. For the purpose of the 
survey a case was defined as any patient in whom the physician suspected that the most likely diagnosis was occupational asthma, defined as asthma which is caused by or made substantially worse by agents encountered in the workplace. Confirmatory investigations were not mandatory because investigations such as bronchial challenge are seldom available in non-specialist centres. Participants included all chest physicians, medical boarding (pneumoconiosis panel) doctors, health and safety doctors, and those members of the West Midlands Group of the Society of Occupational Medicine who wished to take part. Communication was maintained by means of the Midland Thoracic Society Rare Respiratory Disease Registry, which seeks monthly reports from its members about a number of different respiratory diseases. For this study the circulation was expanded to include these other relevant doctors. Participants were asked to return the surveillance form whether or not they had seen cases and peer pressure was used to encourage doctors who repeatedly failed to return the form. Over the year a mean monthly return rate of $86 \%$ of forms was achieved. A short questionnaire was sent for each case. This requested the worker's occupation, employer, agents to which the worker was exposed, and any specific causative agent recognised. It also determined the date of diagnosis; incidence figures were derived from workers first diagnosed in 1989 and prevalence figures were derived from all reported cases. The data from the returned questionnaires were then entered on to a computer database for further analysis. Data from different doctors were correlated to identify common workplaces not previously recognised as a problem. A progress report was circulated to participants every three months.

Regional working population data for use in the calculations were available from the last population census $^{8}$; the area covered by the census region matched closely that of the Regional Health Authority. This was not true, however, at a district level. The regional denominators were composed of workers resident and working in the region and nonresidents working in the region. Residents working outside the region were excluded. Because working population figures were not available at a district health authority level, this analysis was performed on an estimated working population for each district. This estimate was derived using the total population figures for a district health authority and the number of people working in the region as a whole-that is, $2 \cdot 2$ million of $5 \cdot 1$ million.

\section{Results}

In the first 12 months 227 cases of recognised occupational asthma have been detected by the survey; of these 67 were new cases first diagnosed in 1989. Sixty five per cent of these cases were first seen by the authors, $23 \%$ by the medical boarding panel (who see cases for Department of Social Security (DSS) compensation), $10 \%$ by chest physicians, and $2 \%$ by health and safety doctors. Eight per cent of cases were reported by more than one source. The age range of the cases reported was $18-75$ with a mean age of 48 . Eleven were over 65 and $71 \%$ were men. The top four agents to which patients were exposed in the workplace were isocyanates, colophony, flour, and oil mists. These matched closely the top four occupations-namely, paint sprayers, solderers, machine tool operators, and bakers. In 33\% of cases the notifying doctors thought that they had identified a specific causal agent by, for example, bronchial provocation tests or specific immunology.

In the first year the number of new recognised cases in the West Midlands Region was 30 per million of the general working population. Table 1 shows cases found in different occupational groups. Using the home address of the individual workers it was possible to make a first estimate of the prevalence of occupational asthma within district health authorities (table 2). Too few cases were found in the first year to allow calculation of incidence by district health authority.

During the first year the surveillance scheme detected 26 workplaces with more than one symptomatic worker. On one occasion an electroplating factory where no occupational asthma had previously been suspected was independently identified by two

Table 1 Incidence of occupational asthma by occupational group based on newly diagnosed cases reported to the scheme in 1989

\begin{tabular}{lr}
\hline Occupational order & Incidence \\
\hline Painting, repetitive assembling, product packaging, inspecting, and related & 154 per million \\
Material processing; making and repairing (excluding metal and electrical) & 11 per million \\
Farming, fishing, and related & 77 per million \\
Catering, cleaning, hairdressing, and personal services & 50 per million \\
Professional and related in science engineering, technology, and similar fields & 37 per million \\
Processing; making, repairing, and related (metal and electrical) & 36 per million \\
Transport operating, material moving, and storing and related & 15 per million \\
Professional and related in education, welfare, and health & \\
Clerical and related & 3 million \\
Construction, mining, and related not specified elsewhere & No 1989 cases \\
Professional and related supporting management; senior national and local government managers & No 1989 cases
\end{tabular}


Table 2 Prevalence of occupational asthma by district health authority (per million estimated general working population)

\begin{tabular}{ll}
\hline District Health Authority & $\begin{array}{l}\text { Prevalence (number } \\
\text { of old/new cases) }\end{array}$ \\
\hline Solihull & $303(19 / 7)^{\star}$ \\
East Birmingham & $200(17 / 3)^{\star}$ \\
Bromsgrove and Redditch & $164(5 / 4)$ \\
Sandwell & $156(13 / 3)$ \\
South Birmingham & $147(16 / 3)$ \\
Central Birmingham & $119(20 / 7) \dagger$ \\
Mid-Staffordshire & $110(10 / 2)^{\star}$ \\
North Birmingham & $80(5 / 2)$ \\
West Birmingham & $72(3 / 8)$ \\
South East Staffordshire & $71(7 / 1)$ \\
Kidderminster & $58(3 / 2)$ \\
Shropshire & $39(3 / 4)$ \\
South Warwickshire & $37(3 / 1)$ \\
Walsall & $34(5 / 0)$ \\
Wolverhampton & $29(1 / 4)$ \\
Coventry & $28(3 / 2)$ \\
North Staffordshire & $27(5 / 2)^{\star}$ \\
Worcester & $26(2 / 1)$ \\
Hereford & $23(2 / 0)$ \\
Dudley & $23(1 / 1)$ \\
North Warwickshire & $13(1 / 0)$ \\
Rugby & No cases $\ddagger$ \\
\hline &
\end{tabular}

*District with a chest physician with special interest in occupational lung disease.

tSite of the occupational chest clinic.

fDistrict with no chest physician.

doctors as a source of occupational asthma. Further investigation found the cause to be an isocyanate lacquer and appropriate advice has now been given to the company's occupational physician.

\section{Discussion}

Preliminary results from the SWORD project suggest an incidence of notified cases in the West Midlands Metropolitan Council of 66 per million workers and between 20 to 34 million workers for the rest of the West Midlands Region. ${ }^{3}$ Our own survey, confined to occupational asthma, found 30 new cases of recognised occupational asthma per million workers in this region as a whole in 1989. Both incidences are likely to be substantial underestimates of the true incidence of occupational asthma in this region. They do compare, however, with other estimates of incidence of recognised occupational asthma such as 71 per million in a similar working population in Finland in $1982 . .^{910}$ Analysis of specific occupational groups in the region shows a range of incidence from 154 new cases for every million painters and assembly workers per year to three new cases per million clerical workers per year. As expected, the occupations with the largest number of new recognised cases per year were those in which workers were exposed to well recognised sensitising agents such as isocyanates, colophony (including solder flux), and flour. Less widely recognised agents such as oil mists produced by machine tool operation were also implicated in a substantial number of cases. The fact that most cases reported to the survey were seen at our tertiary referral centre may affect the representative nature of the sample. It is noteworthy that asthma arising from exposure to oil mists is not yet recognised for the award of compensation in the United Kingdom. Analysis of the total number of cases of occupational asthma in different district health authorities suggested a more than 10-fold difference in prevalence of reported workers between different health authorities, including workers receiving compensation from the DSS. These differences could be partly explained by the longer follow up of patients in some health authorities, overdiagnosis by interested respiratory and occupational physicians, or underdiagnosis in areas with no interested physician. Some of the evidence suggests that occupational asthma is more frequently diagnosed by physicians with a special interest in occupational lung disease. A similar situation is seen in the results from the SWORD project. This may be because the diagnosis of occupational asthma takes time and enthusiasm, which is often at a premium in outpatient clinics.

The lack of identified cases from some more rural areas is by contrast with the findings in Finland where a large proportion of compensated cases are agricultural workers. ${ }^{11}$

These results represent the first reasonable approximations of the occurrence of recognised occupational asthma for a defined geographical area in the United Kingdom with subanalysis in different occupational groups. They show high risk occupations of which all physicians should be aware and provide evidence of the need for an expansion of the present limited list of 14 agents for which compensation is available. ${ }^{1213}$ The surveillance scheme is ongoing and in the next two years it will concentrate on an audit of how the diagnosis of occupational asthma is made, what underlying mechanisms are suspected by physicians, and what action is taken after diagnosis.

We thank all members of the Midland Thoracic Society, the Medical Boarding Centre (respiratory disease), Stoke on Trent, and other participating physicians. We also thank Mrs Jan Cohen for administering the surveillance scheme.

Requests for reprints to: Dr P F G Gannon, Occupational Lung Disease Unit, East Birmingham Hospital, Bordesley Green East, Birmingham B9 5ST.

1 Blanc P. Occupational asthma in a national disability survey. Chest 1987;92:613-7.

2 Keskinen $H$, Alanko $K$, Saarinen $L$. Occupational asthma in Finland. Clin Allergy 1978;8:569-79.

3 Meredith SK, Taylor VM, McDonald JC. Regional incidence of work-related respiratory disease in the UK, 1989. Thorax 1990;45:783 (abstract). 
4 Salvaggo J, ed. Occupational and environmental respiratory disease in NIAID task force report: asthma and allergic disease. Washington DC: US Department of Health, Education, and Welfare, May 1979. (NIH publ No 79-387.)

5 Kobayashi S. Different aspects of occupational asthma in Japan. In: Frazier CA, ed. Occupational asthma. New York: Van Nostrand Reinhold, 1980:229-44.

6 Burge PS, Perks W, O'Brien IM, Hawkins R, Green M. Occupational asthma in an electronics factory. Thorax 1979; 34:13-8.

7 Musk AW, Venables KM, Crook B, Nunn AJ, Hawkins R, Crook GDW, et al. Respiratory symptoms, lung function, and sensitisation to flour in a British bakery. Br J Ind Med 1989; 46:636-42.

8 Office of Population Censuses and Surveys. Census of England and Wales. London: HMSO, 1981.

9 Vaaranen V, Vasama M. Ammattiaudit v. Helsinki:
Tyoterveyslaitos, 1981 .

10 Keskinen H. Epidemiology of occupational lung disease: asthma and allergic alveolitis. In: Kerr JW, Gonderton MA, eds. Proceedings of the $X I$ international congress of allergology and immunology. London: MacMillan, 1983:403-7.

11 Vaarenen V, Vasama M, Jolanki R, Toikkanen J. Ammattitaudit 1988. Helsinki: Tyoterveyslaitos, 1989.

12 The Social Security (industrial injuries). Prescribed Diseases Regulation. London: HMSO, 1985. (Statutory instrument 967.)

13 The Social Security (industrial injuries and adjudication) Miscellaneous Amendment Regulation. London: HMSO, 1986. (Statutory instrument 1374.)

Accepted 20 May 1991

\section{Vancouver style}

All manuscripts submitted to the $B r J$ Ind Med should conform to the uniform requirements for manuscripts submitted to biomedical journals (known as the Vancouver style).

The Br J Ind Med, together with many other international biomedical journals, has agreed to accept articles prepared in accordance with the Vancouver style. The style (described in full in $\mathrm{Br}$ Med J, 24 February 1979, p 532) is intended to standardise requirements for authors.

References should be numbered consecutively in the order in which they are first mentioned in the text by Arabic numerals above the line on each occasion the reference is cited (Manson ${ }^{1}$ confirmed other reports ${ }^{2-5} \ldots$..). In future references to papers submitted to the $B r J$ Ind Med should include: the names of all authors if there are six or less or, if there are more, the first three followed by et al; the title of journal articles or book chapters; the titles of journals abbreviated according to the style of Index Medicus; and the first and final page numbers of the article or chapter.

Examples of common forms of references are:

1 International Steering Committee of Medical Editors. Uniform requirements for manuscripts submitted to biomedical journals. Br Med J 1979;1:532-5.

2 Soter NA, Wasserman SI, Austen KF. Cold urticaria: release into the circulation of histamine and eosino-phil chemotactic factor of anaphylaxis during cold challenge. N Engl J Med 1976;294:687-90.

3 Weinstein L, Swartz MN. Pathogenic properties of invadins micro-organisms. In: Sodeman WA Jr, Sodeman WA, eds. Pathologic physiology: mechanisms of disease. Philadelphia: W B Saunders, 1974:457-72. 